\title{
Regional Competitiveness as an Aspect Promoting Sustainability of Latvia
}

\author{
By Ilze Judrupa ${ }^{1}$
}

\begin{abstract}
Providing of sustainability is one of the main priorities in normative documents in various countries. Factors affecting regional competitiveness is seen as close to them determining sustainability in many researches. The aim of this research was to identify and evaluate main factors of competitiveness for statistical regions of Latvia to promote sustainable development of the country, applying the complex regional competitiveness assessment system developed by the author. The analysis of the Regional Competitiveness Index (RCI) and its sub-indexes showed that each statistical region has both: factors promoting and hindering competitiveness. Overall the most competitive is Riga statistical region, but the last place takes Latgale statistical region. It is possible to promote equal regional development and sustainability of Latvia by implementing well-developed regional development strategy and National Action Plan. To develop such strategies, it is necessary to understand the concept of sustainable competitiveness. To evaluate sustainable competitiveness of Latvia and its regions it is necessary to develop further the methodology of regional competitiveness evaluation.
\end{abstract}

Keywords: competitiveness, sustainability, factors of competitiveness, matrix of competitiveness level and growth, Regional Competitiveness Index

\section{Introduction}

Providing of sustainability is one of the main priorities in many strategies, development plans and other normative documents in various countries. According to the concept of sustainability, it tights together three main aspects of development - economic, environmental and social - to ensure "meeting the needs of the present without compromising the ability of future generations to meet their needs" (Grant, 2020).

Competitiveness and sustainability are closely related concepts. Increase of regional competitiveness could lead to sustainable development of country and its regions. But it is not possible to achieve exactly the same level of development in all regions. Therefore, the most important task is not to reduce regional disparities, but to make regions an attractive place to live and work, highlighting the advantages of each region and also taking into account the factors that hinder the development of a particular area in a particular region.

It is necessary to develop a scientifically based methodology for determining the competitiveness of the territory and a model for its evaluation, which would allow to identify the factors hindering and promoting development and, consequently, to show the possibility to comply with the principles of sustainability.

The main aim of the research is to identify and evaluate main factors of competitiveness 
for statistical regions of Latvia to promote sustainable development of the country. To achieve the aim, the following tasks were set:

- to do literature review on the concept of national and regional competitiveness;

- to identify relations between competitiveness and sustainability;

- to analyse terms "competitiveness" and "sustainability" in the Latvia's normative documents;

- to select, systematise and analyse factors and indicators of regional competitiveness taking into account specific conditions in Latvia;

- to develop and calculate Regional Competitiveness Index (RCI);

- to develop the method to identify factors that promote or hinder regional competitiveness in Latvia thus influencing sustainability of the country.

Novelty of the research is related to the analysis of terms "competitiveness" and "sustainability" in the Latvia's normative documents; development of the improved model to evaluate regional competitiveness.

Research methods: analysis and synthesis, induction and deduction, literature review, statistical analysis of quantitative data, index calculation method, ranking, validation.

Limitations of the research: research period 2000-2019; only quantitative data were analysed form official statistical sources; due to time and scope of the study only internal factors of regional competitiveness were analysed.

\section{Concept of Regional Competitiveness}

The essence of competitiveness is not just a macroeconomic issue. It also plays a key role at regional, urban and local levels. There is a growing global interest in the competitive potential of individual regions and cities, as well as the question of how to identify the factors influencing regional competitiveness and develop policies that would promote and accelerate the development of these factors.

Research on national and regional competitiveness and its concepts has been developed by several authors, such as: M. Porter (1990, 1998), L. Tyson (1992), M. Storper (1995), P. Krugman (1996), E. Helander (2003), S. Pinch, N. Henry, M. Jenkins, and S. Tallman (2003), F. Kronthaler (2003), M. Kitson, R. Martin, and P. Tyler (2004), E. Malecki (2004, 2007), R. Rowthorn (2005), S. Garelli (2006), A. Pike, A. Rodríguez-Pose, and J. Tomaney (2006), B. A. Gilbert, P. P. McDougall, and D B. Audretsch (2008), H. Y. Cheung and A. W. H. Chan (2011), K. Aiginger, S. Bärenthaler-Sieber, and J. Vogel (2013), J. Kourilova, R. Wokoun, M. Damborsky, and N. Krejcova (2012), M. Delgado, C. Ketels, M. Porter (2012), R. Huggins, H. Izushi, and P. Thompson (2013), R. Camagni and R. Capello (2013), M. Thissen, F. Van Oort, D. Diodato, and A. Ruijs (2013), F. Unterlass et al. (2015), K. Aiginger, M. Firgo (2015), Z. Krzelj-Colovic (2015), C. Ketels (2015), M. Muchdie (2017), L. Morin and D. Ramon (2017), Y. Shapoval (2018), V. Januskaite and L. Uziene (2018), J. C. S. de la Vega, J. D. B. Azorín, A. C. Segura, and M. E. Yago (2019). The main scientists from Latvia, who had recently analysed regional competitiveness and its main factors were V. Boronenko (2009), S. Ignatjevs (2010), V. Vesperis (2012), E. Racko (2013), E. Jermolajeva (2018), B. Rivza (2018), Z. Zeibote (2018), I. Judrupa and M. Senfelde (2018). The literature review on concept of national and regional competitiveness shows that 
competitiveness drivers for nations and regions are almost the same thus it is possible to use concepts developed for countries to develop concept of regional competitiveness. Mashokhida, Avezov, Palka, and Shakhlo (2018) also concludes the same according to sustainability indicators - the indicators of sustainability of the higher-level systems can serve as indicators of regional sustainability. But despite this fact regional dimension nowadays becomes increasingly important because even in the same country, a certain level of differentiation may be observed (Januskaite \& Uziene, 2018). The concept of national and regional competitiveness and theoretical foundations have historically developed over a long period of time, which has allowed to define various drivers of competitiveness (see Fig.1).

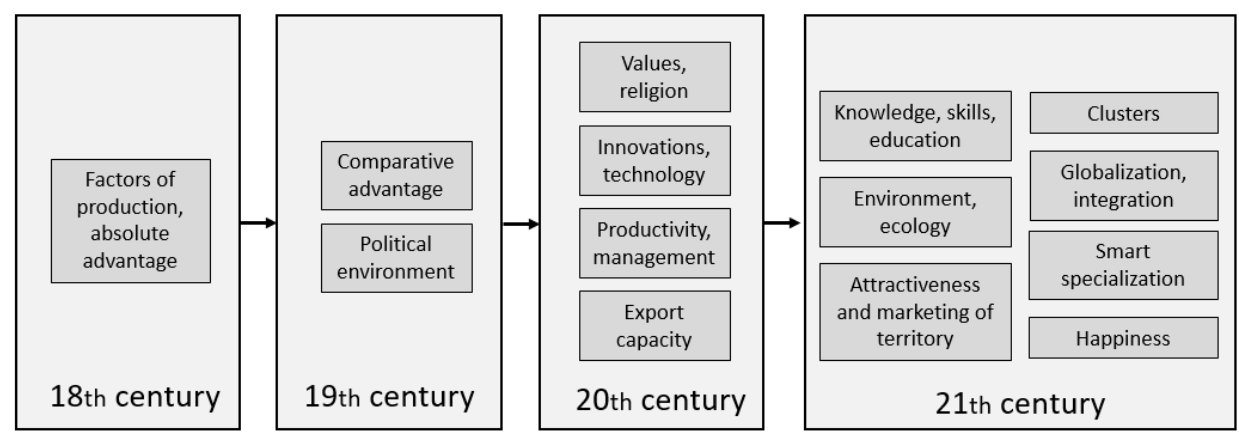

Fig.1. Development of national and regional competitiveness drivers over centuries (made by the author based on literature review)

One of the founders of the national competitiveness concept is D. Ricardo, who developed A. Smith's idea of absolute advantage and created the concept of comparative advantage. The principle of absolute advantages of A. Smith excluded the possibility to import goods whose production costs in the country were lower. Such goods had to be produced in the country. Ricardo concluded that it is also possible to import goods whose production costs in the country were lower. A. Smith based the advantages of the countries in foreign trade on division of labour, specialization and absolutely different production costs, but D. Ricardo - on the restriction of capital migration, market protection rules and relatively different production costs (Krilovs, 2014).

The further evolution of the concept of competitiveness is related to the economic systems existing in the countries in specific time periods, the development trends of economic theory, the ongoing economic integration and the development of new industries. In the 19th century the socio-political environment in the country appeared as an important aspect of competitiveness. At the beginning of the 20 th century, innovations are mentioned as one of the factors ensuring competitiveness. Thanks to the development of new, science-intensive industries, the concept of competitiveness is increasingly linked to education, knowledge, technological development and innovation. In recent years, the concept of competitiveness has begun to be linked to sustainable development, ecological factors, smart specialization and even efforts to define happiness as one of the key factors in competitiveness. 


\section{Relations between Competitiveness and Sustainability}

A new concept of "Sustainable competitiveness" was introduced by Balkyte and Tvaronaviciene in 2010. Political topicalities raised a need for development of this new concept of the competitiveness and revealing relationships between sustainable development and competitiveness (Balkyte \& Tvaronaviciene, 2010).

Nowadays there are more and more investigations in the field of sustainable competitiveness at regional level. There is a wide range of regional competitiveness researches with the focus on one or another aspect of sustainability, for example environment (Ivanov, 2019a), environment sustainability and energy saving (Yfanti, Sakkas, Vailakis, \& Nistikaki, 2019); natural resources and environment protection (Anicic J., Anicic D., \& Kvrgic, 2019); or researches that provide a deeper look at sustainable competitiveness and observe many factors (for example Herciu and Ogrean, 2014; Despotovic D., Cvetanovic, Nedic, and Despotovic M., 2016). However, many researches still stream focus on the environment and the economy, or on the economy and its social aspects, with both the environmental and social elements of sustainable development rarely studied in tandem with economic growth. Sustainable competitiveness as a concept and as an approach bridges this gap by merging measures of environmental and social sustainability into a synthetic competitiveness framework (Doyle \& Perez-Alaniz, 2017). Andreoni and Miola (2016) developed a technical report on competitiveness and sustainable development goals for European Commission. In this research the definition of sustainable competitiveness was "based on the idea that competitiveness today should be reached without compromising the possibility of competitiveness tomorrow. Sustainable competitiveness is defined as the set of institutions, policies and factors that make a nation productive over the longer term, while ensuring social and environmental sustainability". (Andreoni \& Miola, 2016, p.13).

World Economic Forum tried to improve Global Competitiveness Index (GCI) by adding two more pillars of sustainability: social and environmental sustainability. They calculated Sustainability adjusted GCI for 2014-2015. The findings showed that, irrespective of their level of competitiveness, on the two elements of sustainability countries were able to attain results that were above or below their competitiveness score. However, the observations were that countries in the top half of the competitiveness rankings tent to perform better on sustainability as well (Corrigan, Crotti, Hanouz, \& Serin, 2014). In 2019 their conclusions were similar - countries with the same level of competitiveness were able achieve very different environmental and societal outcomes, because of different priorities and policy choices made over the course of many years (Schwab, 2019).

SolAbility (a Swiss-Korean joint-venture) developed the Global Sustainable Competitiveness Index. It is published annually since 2012 and it measures current and future capability of countries to generate and/or sustain financial and non-financial income and wealth for its population. The Global Sustainable Competitiveness Index is based on 109 quantitative performance indicators, grouped in the 5 pillars of sustainable competitiveness: natural capital, resource intensity, intellectual capital, social cohesion, and governance (SolAbility, 2020).

Competitiveness is a complex economic category that is closely related to the country's sustainability (Okuneviciute Neverauskiene, Danileviciene, \& Tvaronaviciene, 2020). 
Sustainable competitiveness includes several interrelated aspects of the concept of sustainable development. But there is one important problem with evaluation of competitiveness and sustainability at regional level, because the preliminary analysis of situation in different countries show that the most known and used ways for analysing sustainable development are inapplicable at regional and local levels because of lack or inaccessibility of open data at these levels (Ivanov, 2019b). It means that it is necessary to select, systematise and analyse factors and indicators of regional competitiveness taking into account specific conditions in Latvia.

\section{Competitiveness and Sustainability in Normative Documents of Latvia}

In Latvia, several laws and normative documents related to ensuring balanced regional development have been developed and adopted. The author of the article made the content analysis of them to find out what is the concept of competitiveness in normative documents in Latvia (see Table 1).

Table 1: Concept of competitiveness in the normative documents of Latvia (made by the author)

\begin{tabular}{|c|c|c|}
\hline $\begin{array}{l}\text { Name of the } \\
\text { normative document }\end{array}$ & Drivers of competitiveness & $\begin{array}{l}\text { Result of } \\
\text { competitiveness }\end{array}$ \\
\hline $\begin{array}{l}\text { Concept of Latvia's regional } \\
\text { development policy } \\
(05.12 .1996)\end{array}$ & $\begin{array}{l}\text { Competitive products } \\
\text { Education, competitive workforce }\end{array}$ & Development \\
\hline $\begin{array}{l}\text { Regional Policy Guidelines } \\
(02.04 .2004)\end{array}$ & $\begin{array}{l}\text { Social infrastructure, investments, transport } \\
\text { infrastructure, innovations, science and education }\end{array}$ & Quality of life \\
\hline \begin{tabular}{|l|} 
Regional Policy Guidelines \\
for 2013-2019 \\
$(29.10 .2013)$ \\
\end{tabular} & $\begin{array}{l}\text { Creative industries, infrastructure, polycentric } \\
\text { development, natural resources, human resources, } \\
\text { innovations, skills etc. }\end{array}$ & Development \\
\hline $\begin{array}{l}\text { Regional Policy Guidelines } \\
\text { for 2021-2027 } \\
(26.11 .2019)\end{array}$ & $\begin{array}{l}\text { business environment, productivity, human capital, } \\
\text { efficiency of services (smart solutions), innovation, } \\
\text { knowledge, transport infrastructure, accessibility and } \\
\text { living environment, efficiency of administrative work. }\end{array}$ & Quality of life \\
\hline \begin{tabular}{|l|} 
Latvian National \\
Development Plan 2007- \\
2013 (2006) \\
\end{tabular} & $\begin{array}{l}\text { Competitive products, education, skills, technologies, } \\
\text { coordinated knowledge flow, knowledge management, } \\
\text { export capacity, creative industries }\end{array}$ & $\begin{array}{l}\text { Sustainability, } \\
\text { development }\end{array}$ \\
\hline $\begin{array}{l}\text { National Development Plan } \\
\text { of Latvia for 2014-2020 } \\
\text { (2012) }\end{array}$ & $\begin{array}{l}\text { Exportable products, favourable business } \\
\text { environment, research, innovation, education, } \\
\text { competencies, energy efficiency, human capital, } \\
\text { growth-supporting territories - availability of services, } \\
\text { use of territorial potential, natural and cultural capital, } \\
\text { health }\end{array}$ & $\begin{array}{l}\text { Growth, economic } \\
\text { breakthrough, well-being }\end{array}$ \\
\hline $\begin{array}{l}\text { National Development Plan } \\
\text { of Latvia for 2021- } \\
\text { 2027(NDP2027) (2020) }\end{array}$ & $\begin{array}{l}\text { Exportable products, green economy, knowledge and } \\
\text { innovation, research and science, education, inclusive } \\
\text { society, competitive enterprises, cross-sectoral } \\
\text { cooperation, transport infrastructure, smart } \\
\text { governance, regional development }\end{array}$ & $\begin{array}{l}\text { Sustainability, quality of } \\
\text { life, long-term growth, } \\
\text { productivity, equal rights }\end{array}$ \\
\hline $\begin{array}{l}\text { Sustainable Development } \\
\text { Strategy of Latvia until } \\
2030 \text { (Latvia 2030) } \\
(2010)\end{array}$ & $\begin{array}{l}\text { Cultural capital, human capital, education, innovation, } \\
\text { natural capital, spatial development, innovative } \\
\text { governance, public participation }\end{array}$ & $\begin{array}{l}\text { Sustainability, growth, } \\
\text { quality of life, social } \\
\text { cohesion }\end{array}$ \\
\hline
\end{tabular}


From Table 1 it is possible to see that there are many normative documents related to the regional development and competitiveness of Latvia. The hierarchically highest nationallevel, long-term planning document is Latvia 2030. NDP 2027 is Latvia's main mediumterm development planning document. All other documents are hierarchically below those two. There are many different factors or drivers of competitiveness mentioned in the legal acts of Latvia and the main outcomes should be high level of quality of life, rapid economic growth and high level of socio-economic development of the country, as well as sustainability and welfare of population.

But there are also several laws in the area of regional development in which "competitiveness" is not described or mentioned. Competitiveness was not mentioned in the following laws: Law on Specially Supported Regions (22.05.1997, expired on 23.04.2002), Law on Territorial Development Planning (15.10.1998, expired on 16.06.2002), Spatial Planning Law (22.05.2002, expired on 01.12.2011), Regional Development Law (21.03.2002), Development Planning System Law (08.05.2008), Law on Territorial Development Planning (13.10.2011), Procedures for Monitoring and Evaluation of Regional Development (01.07.2014), and Action plan for economic growth of Latgale region $2018-2021$ (19.09.2018). It is understandable that there was nothing written about competitiveness and sustainability in the oldest normative documents. But the laws and regulations adopted so far in Latvia do not provide the definition of competitiveness. Increasing competitiveness is emphasized as a tool to achieve a goal. The main goals are related to the sustainable and balanced development of the regions of Latvia. But there is the lack of understanding concepts of "competitiveness" and "sustainable competitiveness" in Latvia.

Examining the nature of competitiveness, it becomes clear that it is not possible to analyse the competitiveness of goods, companies, industries, regions and countries in the same way. However, the different levels of competitive advantage are closely linked, so it is possible to conclude that:

- competitiveness is a multi-level concept. A wide variety of entities compete with each other - types of goods, companies, organizations, industries, regions, individual countries or their associations;

- the competition is different at different levels, so the concept of competitiveness will be different for each level;

- all economic levels are closely interlinked; it means that the definition of competitiveness requires a structural analysis that allows all levels to be linked.

Competitiveness is a wide concept and could be analysed from different points of view. Analysing the existing research on the essence of competition and competitiveness, the author concludes that the essence of competition is the same at all levels - competition is a "fight". There will be only a different object of competition at each level. At the level of companies and industry, there is a fight for selling a product or service that will ensure the company's survival in a competitive environment. At regional and national level, there is a fight for investment and labour to ensure higher level of prosperity and sustainability.

\section{Methodology of Development of the Regional Competitiveness Index (RCI)}

Competitiveness can only be determined in comparison with other similar objects. 
Competitiveness assessment criteria can be defined in different aspects depending on the task and goal to be solved. Therefore, one of the most important tasks is the selection of indicators characterizing the competitiveness of the region, so that they reflect the positive aspects of development, efficiency and negative consequences, as well as allow to identify the necessary changes in activities to promote sustainability. An optimal system of indicators would allow to understand the regularities that determine and influence the competitiveness of the regions, to forecast the further development trends and the necessary resources to improve competitiveness.

\subsection{Model of regional competitiveness}

It is necessary to select adequate indicators to calculate indexes and to characterise regional competitiveness. Based on the literature review and analysis of the factors used to calculate international indexes, as well as on the previous research (Judrupa \& Berzina, 2015) the author of the article developed the improved Onion model of factors influencing regional competitiveness (Figure 2).

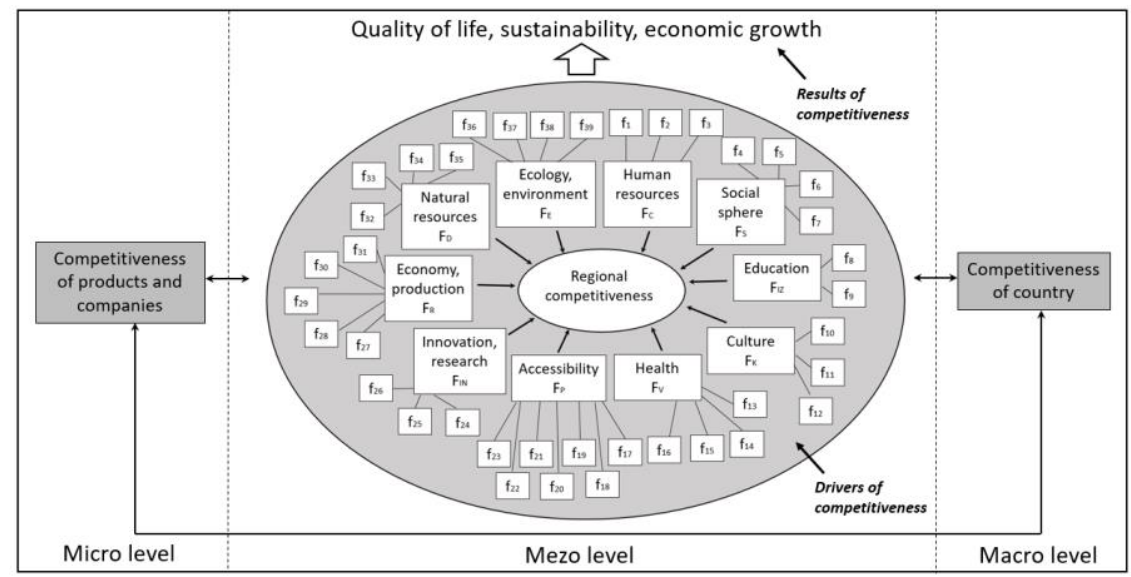

Fig.2. Onion model of regional competitiveness (made by the author)

In Figure 2 it is possible to see that regional competitiveness depends on competitiveness of companies that are producing goods and services in the regions, as well as on the competitiveness of country which represents the external environment of regional competitiveness. The drivers of regional competitiveness are ten different factors interaction and performance of which promotes and ensures higher quality of life, faster economic growth and sustainability. They could be defined as the results of higher or lower competitiveness. To evaluate each of the factors $\left(F_{n}\right)$ specific indicators $\left(f_{n}\right)$ were selected. Since the competitiveness is a complex concept determined by a multiplicity of factors, the most appropriate way to estimate the level of competitiveness is by using multidimensional or composite indicators of competitiveness. Construction of composite indicators could be associated with the dilemma of selecting appropriate variables (individual indicators) and weights representing their relative importance (priority) as well as of choosing an aggregation method (Siudek \& Zawojska, 2014).

Because of the time and scope limitations of the research it was possible to evaluate only the 
drivers of competitiveness at regional level, without assessment of competitiveness of businesses and impact of external environment. One more limitation of the study was the usage of only the official statistical data excluding the qualitative indicators. The developed indicator system for the regional competitiveness evaluation in Latvia is shown in the Table 2.

Table 2: Indicator System for the Regional Competitiveness Evaluation in Latvia (made by the author)

\begin{tabular}{|c|c|c|c|c|c|}
\hline $\mathbf{F}_{\mathrm{n}}$ & $\mathbf{f}_{\mathbf{n}}$ & Name of indicators & $\mathbf{F}_{\mathrm{n}}$ & $f_{n}$ & Name of indicators \\
\hline \multirow[t]{4}{*}{$\mathrm{F}_{\mathrm{C}}$} & $\mathrm{f}_{1}$ & Number of inhabitants, people & \multirow[t]{4}{*}{$F_{S}$} & $\mathrm{f}_{4}$ & Unemployment rate, $\%$ \\
\hline & $f_{2}$ & Proportion of population under working age, $\%$ & & $\mathrm{f}_{5}$ & $\begin{array}{l}\text { Average monthly net wage of } \\
\text { workers, EUR }\end{array}$ \\
\hline & \multirow[t]{2}{*}{$\mathrm{f}_{3}$} & \multirow[t]{2}{*}{ Proportion of working age population, $\%$} & & $\mathrm{f}_{6}$ & Housing stock per inhabitant, $m^{2}$ \\
\hline & & & & $f_{7}$ & $\begin{array}{l}\text { Proportion of guaranteed minimum } \\
\text { income benefit recipients in total } \\
\text { regional population, } \%\end{array}$ \\
\hline \multirow[t]{3}{*}{$\mathrm{F}_{\mathrm{IZ}}$} & \multirow[t]{2}{*}{$\mathrm{f}_{8}$} & \multirow{2}{*}{$\begin{array}{l}\text { Proportion of population with vocational education, } \\
\text { secondary vocational education and general secondary } \\
\text { education of the total regional population (15-74 } \\
\text { years), \% }\end{array}$} & \multirow[t]{3}{*}{$\mathrm{F}_{\mathrm{K}}$} & $\mathrm{f}_{10}$ & Public library readership, people \\
\hline & & & & $f_{11}$ & Number of museums, museums \\
\hline & $f_{9}$ & $\begin{array}{l}\text { Proportion of population with higher education of the } \\
\text { total regional population ( } 15-74 \text { years), } \%\end{array}$ & & $\mathrm{f}_{12}$ & $\begin{array}{l}\text { Proportion of traditional culture and } \\
\text { amateur art participants of the total } \\
\text { regional population, } \%\end{array}$ \\
\hline \multirow[t]{7}{*}{$\mathrm{F}_{\mathrm{V}}$} & $f_{13}$ & Number of doctors per 1000 inhabitants, people & \multirow[t]{7}{*}{$\mathrm{F}_{\mathrm{P}}$} & $f_{17}$ & $\begin{array}{l}\text { Distance from district centers to } \\
\text { Riga, } k m\end{array}$ \\
\hline & \begin{tabular}{|l|}
$f_{14}$ \\
\end{tabular} & $\begin{array}{l}\text { Medical personnel with secondary medical education } \\
\text { per } 1000 \text { inhabitants, people }\end{array}$ & & $\mathrm{f}_{18}$ & $\begin{array}{l}\text { National and municipal road density, } \\
\text { km per } 1000 \mathrm{~km}^{2}\end{array}$ \\
\hline & $\mathrm{f}_{15}$ & Number of hospital beds, beds & & $\mathrm{f}_{19}$ & $\begin{array}{l}\text { Loaded and unloaded cargos in ports, } \\
t\end{array}$ \\
\hline & \multirow[t]{4}{*}{$f_{16}$} & \multirow[t]{4}{*}{ Number of deaths per 1000 inhabitants, people } & & $\mathrm{f}_{20}$ & $\begin{array}{l}\text { Number of passengers arriving and } \\
\text { leaving with passenger ships and } \\
\text { ferries, people }\end{array}$ \\
\hline & & & & $f_{21}$ & $\begin{array}{l}\text { Number of passengers arriving and } \\
\text { leaving from airports, people }\end{array}$ \\
\hline & & & & $f_{22}$ & $\begin{array}{l}\text { Availability of computers in } \\
\text { households, } \%\end{array}$ \\
\hline & & & & $\mathrm{f}_{23}$ & $\begin{array}{l}\text { Availability of Internet in households, } \\
\%\end{array}$ \\
\hline \multirow[t]{5}{*}{$\mathrm{F}_{\mathrm{IN}}$} & \multirow[t]{2}{*}{$f_{24}$} & \multirow{2}{*}{$\begin{array}{l}\text { Proportion of enterprises performing research among } \\
\text { active enterprises in the region, } \%\end{array}$} & \multirow[t]{5}{*}{$\mathrm{F}_{\mathrm{R}}$} & $\mathrm{f}_{27}$ & GDP per employee, EUR \\
\hline & & & & $\mathrm{f}_{28}$ & $\begin{array}{l}\text { Economically active enterprises per } \\
1000 \text { inhabitants, enterprises }\end{array}$ \\
\hline & \multirow[t]{2}{*}{$\mathrm{f}_{25}$} & \multirow{2}{*}{$\begin{array}{l}\text { Proportion of employees in enterprises performing } \\
\text { research of the total number of workers in the region, } \\
\%\end{array}$} & & $\mathrm{f}_{29}$ & $\begin{array}{l}\text { Added value of agriculture sector per } \\
\text { inhabitant, EUR per inhabitant }\end{array}$ \\
\hline & & & & $\mathrm{f}_{30}$ & $\begin{array}{l}\text { Added value of industrial sector per } \\
\text { inhabitant, EUR per inhabitant }\end{array}$ \\
\hline & $f_{26}$ & Total expenditure for research, EUR & & $\mathrm{f}_{31}$ & $\begin{array}{l}\text { Added value of service sector per } \\
\text { inhabitant, EUR per inhabitant }\end{array}$ \\
\hline \multirow[t]{4}{*}{$\mathrm{F}_{\mathrm{D}}$} & $\mathrm{f}_{32}$ & Territory, thousand $\mathrm{km}^{2}$ & \multirow[t]{4}{*}{$\mathrm{F}_{\mathrm{E}}$} & $\mathrm{f}_{36}$ & Municipal waste per $1 \mathrm{~km}^{2}, t$ \\
\hline & $\mathrm{f}_{33}$ & Sea border, km & & $\mathrm{f}_{37}$ & Hazardous waste per $1 \mathrm{~km}^{2}, t$ \\
\hline & $f_{34}$ & Total stocks of construction materials, $\%$ & & $f_{38}$ & $\begin{array}{l}\text { Harmful emissions into the } \\
\text { atmosphere, } t\end{array}$ \\
\hline & $\mathrm{f}_{35}$ & Forest cover, $\%$ & & $f_{39}$ & $\begin{array}{l}\text { Polluted wastewater proportion of } \\
\text { the total wastewater, } \%\end{array}$ \\
\hline
\end{tabular}


From Table 2 it is obvious that in total 10 factors and 39 indicators have been selected. The choice of the number of indicators depended on the availability of statistics and the field that indicators characterised as it was important that the indicators did not overlap.

\subsection{Function of the RCI} Formula 1.

The RCI was calculated as an arithmetical mean of all sub-indexes by using

$R C I=\frac{F_{C}+F_{S}+F_{I Z}+F_{K}+F_{V}+F_{P}+F_{I N}+F_{R}+F_{D}+F_{E}}{N} \rightarrow \max$,

where:

RCI - the Regional Competitiveness Index;

$\mathrm{F}_{\mathrm{C}}$ - sub-index of human resources;

FS - sub-index of social sphere;

$\mathrm{F}_{\mathrm{IZ}}$ - sub-index of education;

$F_{P}$ - sub-index of accessibility;

$F_{I N}$ - sub-index of innovations;

$\mathrm{F}_{\mathrm{K}}$ - sub-index of culture;

$\mathrm{F}_{\mathrm{R}}$ - sub-index of economy and production;

$\mathrm{F}_{\mathrm{V}}$ - sub-index of health care;

$F_{D}$ - sub-index of natural resources;

$\mathrm{F}_{\mathrm{E}}$ - sub-index of ecology;

$\mathrm{N}$ - number of sub-indexes

To develop function of the RCI it was necessary to choose optimal method for normalization of indicators. The sub-index $F_{n}$ of each factor is calculated by taking into account the characterising indicators of the factor, applying the min-max normalisation [$1 ; 1]$. In order to maintain the values of the index in the interval from - 1 to 1 the arithmetic mean of indicators is calculated by using Formula 2 (Judrupa \& Senfelde, 2018).

$F_{n}=\frac{1}{N}\left(\left(2 * \frac{f_{1}-f_{\min _{1}}}{f_{\text {max }_{1}}-f_{\text {min }_{1}}}-1\right)+\left(2 * \frac{f_{2}-f_{\text {min }_{2}}}{f_{\max _{2}}-f_{\text {min }_{2}}}-1\right)+\ldots+\left(2 * \frac{f_{n}-f_{\text {min }_{n}}}{f_{\text {max }_{n}}-f_{\text {min }_{n}}}-1\right)\right.$,

where:

$\mathrm{F}_{\mathrm{n}}$ - sub-index of the regional competitiveness factors;

$f_{1} \ldots f_{n}$ - the actual values of the indicators;

$f_{\min }, f_{\max }$ - the minimum and maximum values of the indicators;

$\mathrm{N}-$ the number of the indicators.

\subsection{Matrix for evaluation of regional competitiveness factors}

In the analysis of the regional competitiveness it is very important which of the competitiveness indicators are promoting competitiveness or on the contrary hinders the increase of the competitiveness in the region. In order to determine whether the indicator is facilitating competitiveness or hindering both its development tendencies and the competitiveness level (according to Formula 1) have to be calculated. In order to evaluate this, the value of a specific region was compared to the average value 0 and the average growth rate of each indicator was calculated by using Formula 3 (Judrupa \& Senfelde, 2018):

$T_{n}=\frac{1}{n}\left(\frac{f_{1}-f_{0}}{f_{0}}+\frac{f_{2}-f_{1}}{f_{1}}+\ldots+\frac{f_{n}-f_{n-1}}{f_{n-1}}\right)$,

where:

$T_{n}$ - the growth rate of the specific factor;

$f_{1} \ldots f_{n}$ - the value of the indicator in the current year;

$f_{0} \ldots f_{n-1}$ - the value of the indicator in the previous year;

$\mathrm{n}-$ number of years. 
Competitiveness level / Growth rate matrix was developed to evaluate whether the specific factor is facilitating or hindering competitiveness of regions.

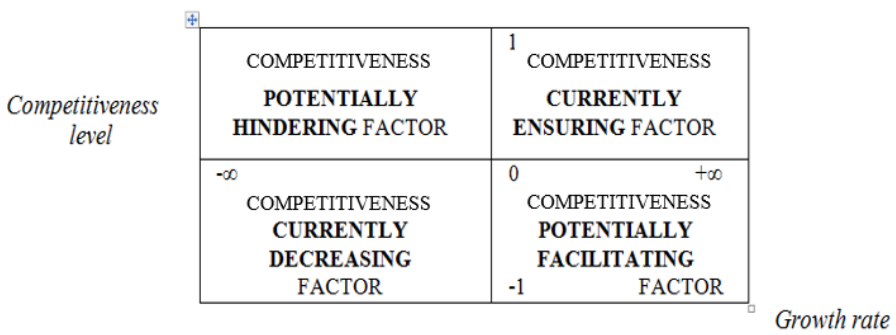

Fig.3. Matrix of the competitiveness factors for regions (Judrupa and Senfelde, 2016)

In Figure 3 it can be seen that development currently ensuring are those factors that have been with a positive growth rate and have ensured the region's indicator above the average competitiveness level. Development currently decreasing are those factors that showed a negative growth and determined the region's ranking below the average competitiveness level. If the development influencing factor in regions is above the average compared to other regions but its development tendency is negative, then in future if this tendency continues to be the same the region can become less competitive. Such factors are competitiveness potentially hindering. If the indicator is comparatively low (below the average level) but with a tendency to improve then in future if this tendency persists the given factor can become competitiveness facilitating.

\section{Results of Calculations - Competitiveness of the Statistical Regions of Latvia}

The scale of the research is Mezo level or statistical regions of Latvia and they are showed in the Figure 4.

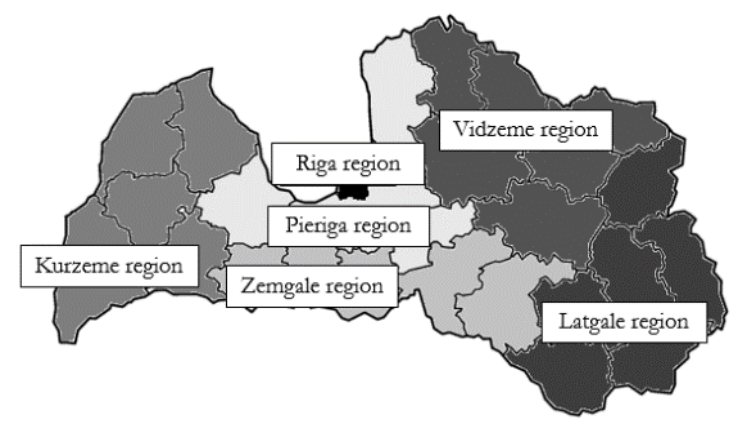

Fig.4. Statistical regions of Latvia (Judrupa and Senfelde, 2018)

On the 26th of May, 2003 a Regulation (EC) No 1059/2003 of the European Parliament and of the Council on the establishment of a common classification of territorial units for statistics (NUTS) was adopted, which entered into force on the $11^{\text {th }}$ of June, 2003 (Regulation (EC) No 1059/2003, 2003). Under this Regulation, three NUTS levels are 
defined, with minimum and maximum populations in the areas. Statistical regions of Latvia are NUTS 3 level regions. Riga region is the smallest one and it is the capital of Latvia. But it is the cultural, scientific, business centre of the country and its population is $33 \%$ of the total population of Latvia.

\subsection{RCI for statistical regions of Latvia}

The methodology recommended by the author of the article envisages to determine the RCI on the basis of 10 main factors. As each of these factors influences the regional competitiveness a specific sub-index is calculated for evaluation of the factor. The overall RCI is formed as a complex indicator from the mentioned sub-indexes by using Formula 1. The results of the RCI calculation for statistical regions of Latvia are illustrated in the Figure 5.

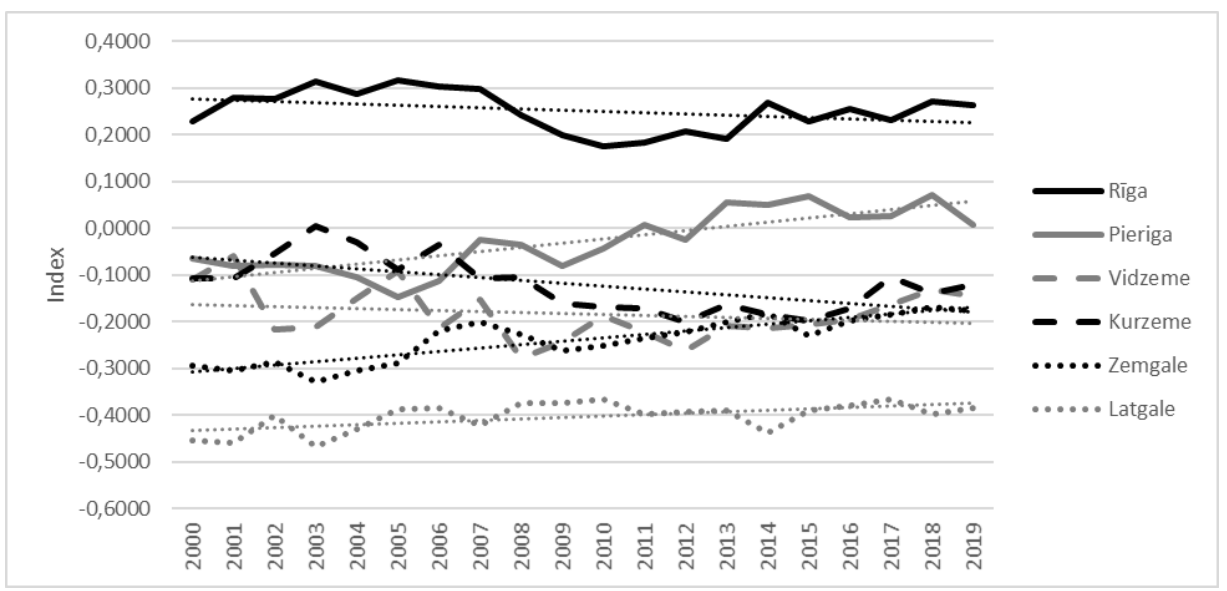

Fig.5. RCI and its trend lines in statistical regions of Latvia (author's calculations based on statistics from Central Statistical Bureau of Latvia; Latvian Centre for Environment, Geology and Meteorology; State Forest service)

Figure 5 shows that the most competitive is the Riga statistical region, whose RCI in 2019 was 0,2626 . The index of Riga region differed significantly from other statistical regions, especially for the period 2000-2007. RCI in 2000-2012 was negative for all other regions, but Pieriga region showed one of the highest increases of competitiveness and its RCI was positive from 2013 onwards. If to compare RCI results of 2000 with the results of 2019, the competitiveness of the regions has increased in the statistical regions of Pieriga, Zemgale and Latgale. The differences between Riga statistical region and Pieriga and Zemgale regions have decreased, but differences in competitiveness levels of Riga and Kurzeme regions have increased. It's not possible to talk about levelling out regional disparities among all regions of Latvia.

\subsection{Example of placement of indicators in the Competitiveness level / Growth rate matrix}

To illustrate process of evaluation whether the indicator is facilitating or hindering competitiveness of region the author chose to show the example of placement of indicators $\left(\mathrm{f}_{1}, \mathrm{f}_{2}, \mathrm{f}_{3}\right)$ characterising the Human resources' factor $\left(\mathrm{F}_{\mathrm{C}}\right)$ in the matrix. 


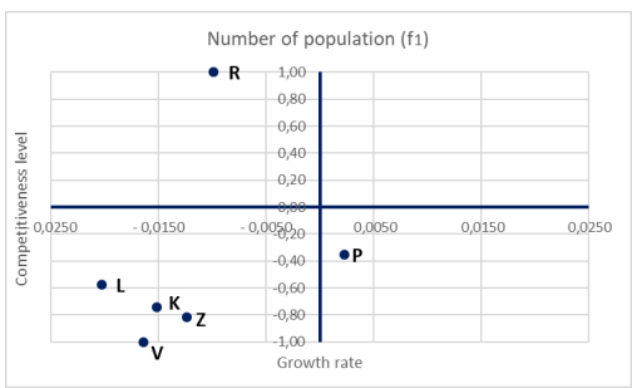

Proportion of working age population ( $\mathrm{f} 3$ )

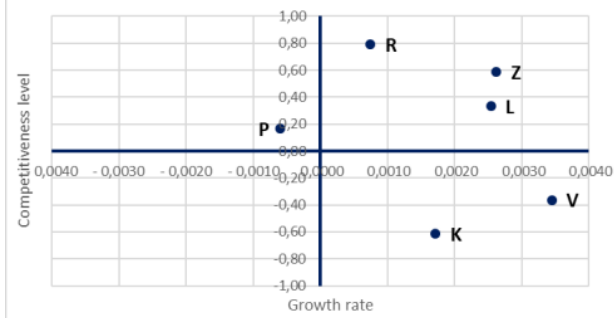

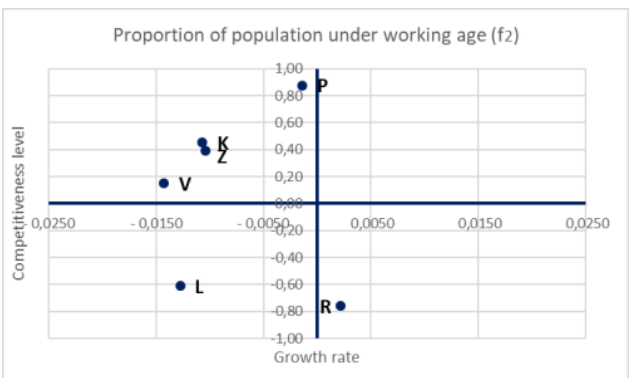

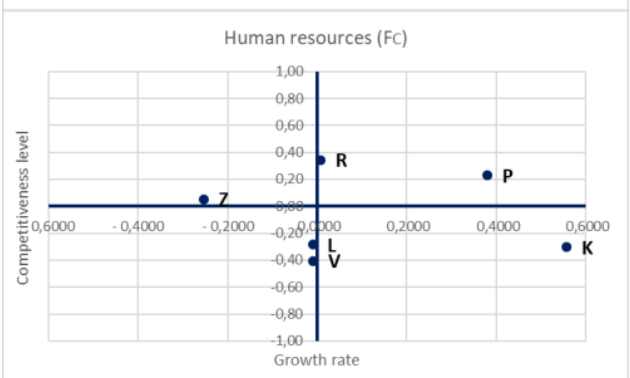

Fig.6. Placement of Human resource factor $\left(F_{C}\right)$ and its characterising indicators in the Competitiveness level / Growth rate matrix (author's calculations)

The analysis of Human resources shows that it could be considered as factor currently ensuring competitiveness in Riga and Pieriga regions. It is a factor that currently decreases competitiveness in Latgale and Vidzeme regions, because the competitiveness level is low and at the same time the development tendencies are negative. For Zemgale region human resources is a factor that potentially could hinder competitiveness of the region, because now the level of competitiveness is comparatively high, but it has negative growth rate. And finally, human resources are a factor that could facilitate competitiveness of Kurzeme region in future, because now the level of competitiveness is low, but the positive growth is observed for this factor. In the same manner it is possible to look deeper at the human resources and analyse all indicators used to calculate Human resources sub-index. During the research author of the article analysed all factors and indicators used to calculate RCI and their placement in the Competitiveness level / Growth rate matrix.

\subsection{Evaluation of factors facilitating or hindering competitiveness of the regions}

However, the analysis of the RCI sub-indexes revealed that each statistical region has both competitiveness-facilitating and competitiveness-hindering factors. The levels of competitiveness of Latvia's statistical regions by sub-indexes of the RCI are shown in Figure 7. 


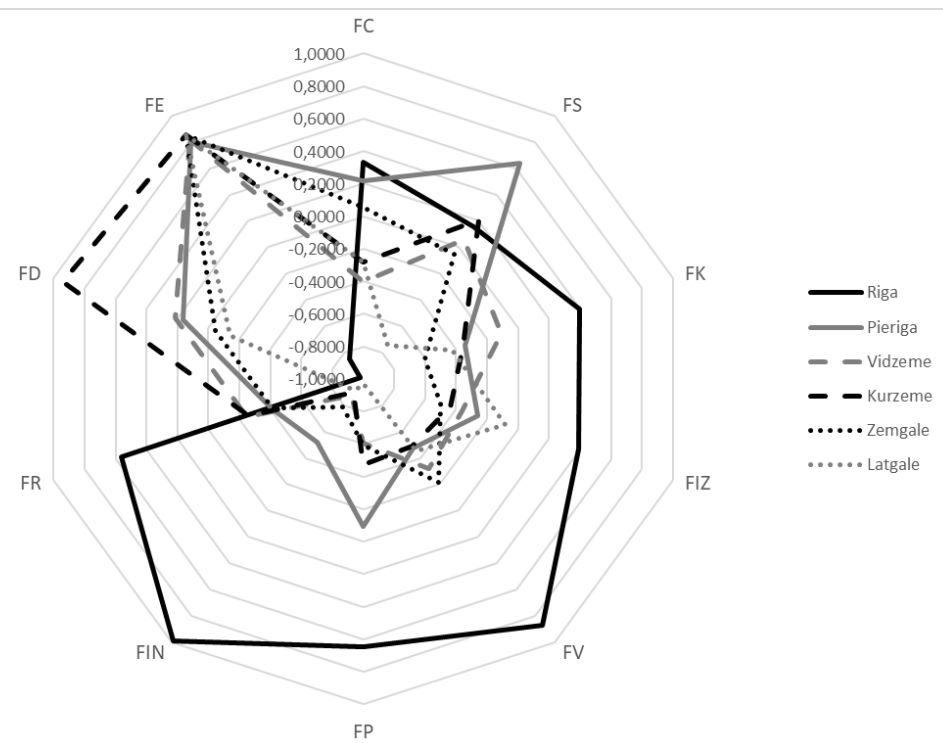

Fig.7. The average level of competitiveness of Latvia's statistical regions broken down by RCI sub-indexes for 20002019 (author's calculations)

Figure 7 shows that the most competitive is the Riga region, for which the radar graph is the widest. Latgale statistical region is the least competitive. However, it is also clear that each region has its own competitive areas. For Riga region they are culture, education, health, accessibility, innovation and production. Pieriga region is competitive in terms of human resources, social area and ecology. The most competitive areas of Kurzeme region are the existence of natural resources, ecology, as well as the social sphere and production. The most competitive field for Zemgale and Latgale regions is ecology. However, Zemgale region has a relatively higher competitiveness in terms of human resources, social sphere and health, but Latgale region in terms of education and culture.

Based on the analysis of indicators it was concluded that the factors influencing competitiveness may have different effects in different regions. Therefore, when developing a regional development strategy, special attention must be paid to the factors that hinder the development of a given region the most. These are mostly the low level of innovation, insufficient production, social sphere and accessibility in Latgale region, as well as the field of ecology in Riga region. For better understanding of competitiveness driving factors and their changes in the regions of Latvia the author of the article did also the analysis of historical development of Latvia's regions.

\section{Conclusions}

In global practice, there are very different approaches to identifying the factors influencing regional competitiveness, which can be combined into two main ones:

- a macroeconomic approach that takes into account only national or global factors;

- a microeconomic approach that also looks at competitiveness of companies in specific regions. 
Competitiveness drivers for nations and regions are almost the same thus it is possible to use concepts developed for countries to develop concept of regional competitiveness. But at the same time it is not possible to use unmodified models developed for evaluation of national competitiveness to evaluate regional competitiveness because very often there is a lack of all necessary statistics at regional level. The other reason to develop models to evaluate competitiveness of regions is specific factors, drivers of competitiveness for each specific region.

Various factors and indicators are used to evaluate sustainability and competitiveness could be seen as one of the drivers to promote sustainability of regions. Competitiveness is a complex economic category that is closely related to the country's sustainability. The concept of sustainable competitiveness was developed recently, but there is still possibility to improve and develop this concept and methodology of evaluation of sustainable competitiveness in the future.

Laws and regulations adopted so far in Latvia do not provide the definition of competitiveness. The main objectives mentioned in the normative documents are related to the necessity of sustainable and balanced development of the Latvia's regions. There is the lack of understanding concept of "sustainable competitiveness" at the level of public administration in Latvia.

After the analysis of the RCI, it can be concluded that the most competitive is Riga statistical region, Pieriga region takes the $2^{\text {nd }}$ place. Kurzeme and Vidzeme regions share 3-4 places, Zemgale region ranks the second last and Latgale region takes the last place. In 2019 only the Riga and Pieriga regions had the level of competitiveness above the average, in other statistical regions it was below the average. The competitiveness level has increased in Pieriga, Zemgale and Latgale regions. For Latgale region increase of competitiveness is highly desirable, because Latgale takes the last place among all regions of Latvia in terms of competitiveness.

Despite the different levels of competitiveness of statistical regions, each region has its own factors promoting or hindering competitiveness. The most competitivenesspromoting factors are in Riga region, but the least amount of such factors are in Latgale statistical region.

Socio-economic differences have existed in Latvia both during the first state-independence and they continue to exist also nowadays. The accents and main directions of economic activities have changed, but the basic geographical advantages have been and remain unchanged.

To evaluate sustainable competitiveness of Latvia and its regions it is necessary to develop further the methodology of regional competitiveness evaluation and select indicators to calculate Sustainable Regional Competitiveness index (SRCI) for regions of Latvia. It is possible to expand the model of competitiveness by adding indicators from external environment of regions, as well by adding more indicators that characterise sustainability. To highlight the importance of the sustainability factors relative weights could be used to calculate the SRCI for each region.

\section{References}


Aiginger, K., Bärenthaler-Sieber, S., \& Vogel, J. (2013). Competitiveness under New Perspectives. WWW for Europe Policy Paper No.44. Available at: http://www.oecd.org/economy/Competitiveness-underNew-Perspectives.pdf Accessed on 18/10/2020.

Aiginger, K., Firgo, M. (2015). Regional Competitiveness Under New Perspectives. $W W W$ for Europe Policy Paper No.26. Available at: https://www.researchgate.net/publication/283320305 Regional Competitiveness Under_New Perspectives Accessed on 18/10/2020.

Anicic, J., Anicic D., \& Kvrgic, G. (2019). Sustainable growth and regional competitiveness of Serbian economy. Ekonomika, 65 (2), 65-74.

Andreoni, V., Miola, A. (2016). Competitiveness and Sustainable Development. Luxembourg: Publications Office of the European Union. Retrieved from: https://publications.jrc.ec.europa.eu/repository/bitstream /JRC103576/lb-na-28316-en-n.pdf Accessed on 23/10/2020.

Attīstības plānošanas sistēmas likums / Development Planning System Law (08.05.2008). Law of the Republic of Latvia. Likumi.lv. Retrieved from: https://likumi.lv/ta/id/175748-attistibas-planosanas-sistemaslikums Accessed on 06/10/2020.

Balkyte, A., \& Tvaronaviciene, M. (2010). Perception of competitiveness in the context of sustainable development: facets of "sustainable competitiveness". Journal of Business Economics and Management, 11 (2), 341-365.

Boronenko, V. (2009). Klasteru loma reǵiona konkurêtspejjas paangstinäsanä / The role of clusters in the development of regional competitiveness. Summary of the thesis for obtaining the doctoral degree. Latvia: Latvia University of Agriculture. Retrieved from: https://llufb.llu.lv/dissertation-summary/regionaldevelopment/Vera Boronenko Promocijas darba kopsavilkums 2009 LLU EF.pdf Accessed on $30 / 09 / 2020$.

Camagni, R., Capello, R. (2013). Regional Competitiveness and Territorial Capital: A Conceptual Approach and Empirical Evidence from the European Union. Regional Studies, 47, 1383-1402.

Central Statistical Bureau of Latvia. (2020). CSB Database. Retrieved from: https://www.csb.gov.lv/en/statistika/db Accessed on 16/10/2020.

Cheung, H.Y., Chan, A.W.H. (2011). The relationship of competitiveness motive on people's happiness through education. International Journal of Intercultural Relations, 35 (2), 179-185.

Corrigan, G., Crotti, R., Hanouz, M.D., \& Serin, C. (2014) Assessing Progress towards Sustainable Competitiveness. In K. Schwab (ed.). The Global Competitiveness report 2014-2015. World Economic Forum. Retrieved from: http://www3.weforum.org/docs/GCR201415/GCR Chapter1.2 2014-15.pdf Accessed on 22/10/2020

De la Vega, J.C.S., Azorin, J.D.B., Segura, A.C., \& Yago, M.E. (2019). A new measure of regional competitiveness. Applied Economic Analysis, 27 (80), 108-126.

Delgado, M., Ketels, C., \& Porter, M. (2012). The Determinants of National Competitiveness. UK: National Bureau of Economic Research, Cambridge. NBER Working Paper 18249. Retrieved from: https://www.researchgate.net/publication/236903847 The Determinants of National Competi tiveness Accessed on 26/10/2020.

Despotovic, D., Cvetanovic, S., Nedic, V., \& Despotovic, M. (2016). Economic, social and environmental dimension of sustainable competitiveness of European countries. Journal of Environmental Planning and Management, 59 (9), 1656-1678.

Doyle, E., \& Perez-Alaniz, M. (2017). On the Pillars of Sustainable Development: A Sustainable Competitiveness Approach. Retrieved from: https://www.semanticscholar.org/paper/On-thePillars-of-Sustainable-Development- $\% 3$ A-A-Doyle-PerezAlaniz/0ac19425cf993778a37d3514b3e30675af742aac Accessed on 26/10/2020.

Gilbert, B.A., McDougall, P.P., \& Audretsch, D.B. (2008). Clusters, knowledge spill overs and new venture performance: An empirical examination. Journal of Business Venturing, 23 (4), 405-422.

Grant, M. (2020). Sustainability. Investopedia. Retrieved from: https://www.investopedia.com/terms/s/sustainability.asp Accessed on 27/10/2020.

Herciu, M., \& Ogrean, C., (2014). An Overview on European Union Sustainable Competitiveness. Procedia Economics and Finance, Vol.16, 651-656.

Huggins, R., Izushi, H., \& Thompson, P. (2013). Regional Competitiveness: Theories and Methodologies for Empirical Analysis. The Business and Economics Research Journal, 6 (2), 155-172. 
Ignatjevs, S. (2010). Teritorijas märketings kē reǵgiona stratêgiskeäs attistz̈bas factors / Territory marketing as a factor of strategic development of the region. Latvia: Rēzeknes Augstskola.

Ivanov, I. (2019a). The environment at regional level: Study, evaluation and problems. International Multidisciplinary Scientific GeoConference Surveying Geology and Mining Ecology Management, SGEM, 19 (5.3), 793-800.

Ivanov, I. (2019b). An Approach for Survey of the Sustainable Development at Regional Level: Case of Bulgaria. International conference Knowledge-based organization, 25 (1), 249-254.

Januskaite, V., \& Uziene, L. (2018). Intellectual Capital as a Factor of Sustainable Regional Competitiveness. Sustainability, 10 (12), 1-18.

Judrupa, I., \& Berzina, I. (2015). Role of Innovations in the Increasing of Regional Competitiveness in Latvia. Management and Sustainable Development, 51 (2). 19-23.

Judrupa, I., \& Senfelde, M. (2016). Introducing of Smart Work - Opportunity to Increase Economic Development of Municipalities in Latvia. Economic Science for Rural Development: Proceedings of the International Scientific Conference. Jelgava: Latvian University of Agriculture.

Judrupa, I., \& Senflede, M. (2018). Latuijas regíionu konkurètspëjas novertê̌sana / Evaluation of regions' competitiveness in Latvia. Scientific monograph, Latvia: RTU Publishing House.

Ketels, C. (2015). Competitiveness and Clusters: Implications for a New European Growth Strategy. $W W W$ for Europe Working Paper No.84. Retrieved from: https://www.hbs.edu/faculty/Publication\%20Files/WWWforEurope WPS no084 MS48 a00e4 36c-231c-4cbf-90e1-4e8261219b6f.pdf Accessed on 12/10/2020.

Kitson, M., Martin, R., \& Tyler, P. (2004). Regional Competitiveness: An Elusive yet Key Concept. Regional Studies, 38 (9), 991-999.

Kourilova, J., Wokoun, R., Damborsky, M., \& Krejcova, N. (2012). The competitiveness of EU regions, ERSA conference papers ersa12p788, European Regional Science Association. Retrieved from: http://www-sre.wu.ac.at/ersa/ersaconfs/ersa12/e120821aFinal00790.pdf Accessed on $16 / 10 / 2020$.

Krilovs, L. (2014). Ekonomiskäs domas retrospekcija / Retrospection of economic thought. Riga: RTU izdevnieciba.

Krugman, P. (1996). A Country is not a Company. Harvard Business Review, January-February 1996. Retrieved from: https://hbr.org/1996/01/a-country-is-not-a-company Accessed on 30/09/2020

Krumins, G. (2018). Impact of Geopolitical Transformations on the Latvian Economy's Development During the Past 100 Years. In A.Rozenberga., I.Steinbuka, and Z.Ozolina (ed.). Europe 100. After / Before. Riga: Zinātne, 89-107.

Krzelj-Colovic, Z. (2015). Regional competitiveness. Management and organization. 2 (1), 437-445. Retrieved from: https://hrcak.srce.hr/161617 Accessed on 30/09/2020.

Latvian Center for Environment, Geology and Meteorology. (2020). Statistics on water, air pollution and municipal waste. Retrieved from: https://www.meteo.lv/lapas/vide/udens/notekudeni Lnotekudeni?id=1198\&nid=428 Accessed on 28/09/2020.

Latvian National Development Plan 2007-2013. (2006). Ministry of Regional Development and Local Government of the Republic of Latvia. Retrieved from: http://www.aip.lv/files/National development plan 20072013 eng.pdf Accessed on 06/10/2020.

Latvijas reǵionālās attīstības politikas koncepcija / Concept of Latvia's regional development policy. (05.12.1996). Latvijas Vèstnesis, p.2.

Malecki, E. (2004). Jockeying for Position: What It Means and Why It Matters to Regional Development Policy When Places Compete. Regional Studies, 38 (9), 1101-1120.

Malecki, E. (2007). Cities and Regions Competing in the Global Economy: Knowledge and Local Development Policies. Environment and Planning C: Government and Policy, 25 (5), 638-654.

Mashokhida, A., Avezov, A., Palka P., \& Shakhlo, R. (2018). The competitiveness and sustainable economic development of Tajikistan regions. Journal of Competitiveness 10 (1), 73-88.

Morin, L., \& Ramon, D. (2017). Ethnocompetitiveness, relations, and networks: towards rural sustainability. Journal Development in Practice, 27 (7), 1020-1032.

Muchdie, M. (2017). Human development, global competitiveness and happiness: a cross-national path analysis. International Journal of Advanced Research, 5 (10), 779-790.

National Development Plan of Latvia for 2014-2020 (2012). Cross-Sectoral Coordination Centre. Retrieved from: https://www.pkc.gov.lv/images/NAP2020\%20dokumenti/NDP2020 English Final.pdf Accessed on 06/10/2020. 
National Development Plan of Latvia for 2021-2027 (2020). Cross-Sectoral Coordination Centre. Retrieved from: https://www.pkc.gov.lv/sites/default/files/inline-files/NAP2027 ENG.pdf Accessed on $06 / 10 / 2020$.

Okuneviciute Neverauskiene, L., Danileviciene, I., \& Tvaronaviciene, M. (2020) Assessment of the factors influencing competitiveness fostering the country's sustainability. Economic Research - Ekonomska Istraživanja, 33 (1), 1909-1924.

Par īpaši atbalstāmajiem reǵioniem / Law on Specially Supported Regions (22.05.1997). Law of the Republic of Latvia. Likumi.lv. Retrieved from: https://likumi.lv/ta/id/52916-par-ipasi-atbalstamajiemregioniem Accessed on 06/10/2020.

Par Reǵionālās politikas pamatnostādnēm / Regional Policy Guidelines. (02.04.2004). Order of the Cabinet of Ministers No.198. Likumi.lv. Retrieved from: https://m.likumi.lv/doc.php?id=86678 Accessed on $06 / 10 / 2020$.

Par Reǵionālās politikas pamatnostādnēm 2013.-2019. gadam / Regional Policy guidelines for 2013-2019. (29.10.2013). Order of the Cabinet of Ministers No.496. Likumi.lv. Retrieved from: https://likumi.lv/ta/id/261409-par-regionalas-politikas-pamatnostadnem-2013-2019-gadam Accessed on 06/10/2020.

Par Reǵionālās politikas pamatnostādnēm 2021.-2027. gadam / Regional Policy guidelines for 2021-2027. (26.11.2019). Order of the Cabinet of Ministers No.587. Likumi.lv. Retrieved from: https://likumi.lv/ta/id/310954-par-regionalas-politikas-pamatnostadnem-2021-2027-gadam Accessed on 06/10/2020.

Par Rīcības plānu Latgales reǵiona ekonomiskajai izaugsmei 2018.-2021. gadam / Action plan for economic growth of Latgale region 2018-2021 (19.09.2018). Regulations of the Cabinet of Ministers No.447. Likumi.lv. Retrieved from: https://likumi.lv/ta/id/301764-par-ricibas-planu-latgales-regionaekonomiskajai-izaugsmei-2018-2021-gadam Accessed on 06/10/2020.

Pike, A., Rodríguez-Pose, A., \& Tomaney, J. (2006). Local and Regional Development. UK: Routledge.

Pinch, S., Henry, N., Jenkins, M, \& Tallman S. (2003). From 'industrial districts' to 'knowledge clusters': A model of knowledge dissemination and competitive advantage in industrial agglomerations. Journal of Economic Geography 3(4), 373-388.

Porter, M.E. (1990). The competitive advantage of nations. Harvard Business Review, 68 (2), 73-93.

Porter, M.E. (1998). The Adam Smith address: Location, clusters and the "new" microeconomics of competition. Business Economics, 33 (1), 7-13.

Racko, E. (2013). Latvijas reğgionu konkurètspējas novèrtēsana un paaugstinäšanas potenciäls Eiropas Savieñibä / Evaluation of the competitiveness of Latvian regions and potential of its increase in the European Union. Summary of the thesis for obtaining the doctoral degree. Latvia: Daugavpils University. Retrieved from: http://du.lv/wp-content/uploads/2015/12/kopsavilkums racko save-1.pdf Accessed on $21 / 10 / 2020$.

Regulation (EC) No 1059/2003 of the European Parliament and of the Council of 26 May 2003 on the establishment of a common classification of territorial units for statistics (NUTS). EUR-Lex. Retrieved from: https://eur-lex.europa.eu/legal-content/en/ALL/?uri=CELEX:32003R1059 Accessed on 21/10/2020.

Reǵionālās attīstības likums / Regional Development Law (21.03.2002). Law of the Republic of Latvia. Likumi.lv. Retrieved from: https://likumi.lv/doc.php?id=61002 Accessed on 06/10/2020.

Reǵionālās attīstìbas uzraudzības un novērtēšanas kārtība / Procedures for Monitoring and Evaluation of Regional Development (01.07.2014). Regulations of the Cabinet of Ministers No.367. Likumi.lv. Retrieved from: https://likumi.lv/ta/id/267737-regionalas-attistibas-uzraudzibas-un-novertesanaskartiba Accessed on 06/10/2020.

Rivza, B. (Ed.) (2018). Zināsanu ekonomika Latvijas lauku un reǵgionu dživotspējai / Knowledge Economy for the Viability of Rural Areas and Regions of Latvia. Scientific monography. Latvia: Jelgavas tipogrāfija.

Schwab, K. (Ed.) (2019) The Global Competitiveness report 2019. World economic Forum. Retrieved from: http://www3.weforum.org/docs/WEF TheGlobalCompetitivenessReport2019.pdf Accessed on $27 / 10 / 2020$

Shapoval, Y. (2018). The marketing role in improving the competitiveness of the region. Baltic Journal of Economic Studies, 3 (4), 289-293.

Siudek, T. \& Zawojska, A. (2014). Competitiveness in the economic concepts, theories and empirical research. Oeconomia, 13 (1), 91-108. 
SolAbility (2020). The Global Sustainable Competitiveness Index. Retrieved from: http://solability.com/theglobal-sustainable-competitiveness-index/the-index Accessed on 12/10/2020.

State Forest Service (2020). Statistics on forests. Retrieved from: https://www.vmd.gov.lv/valsts-mezadienests/statiskas-lapas/publikacijas-un-statistika/meza-statistikas-cd?nid=1809\#jump Accessed on $20 / 09 / 2020$.

Sustainable Development Strategy of Latvia until 2030 (2010). Saeima of the Republic of Latvia. Retrieved from: https://www.pkc.gov.lv/sites/default/files/inline-files/LIAS 2030 en 1.pdf Accessed on $06 / 10 / 2020$.

Teritorijas attīstības plānošanas likums / Law on Territorial Development Planning (15.10.1998). Law of the Republic of Latvia. Likumi.lv. Retrieved from: https://likumi.lv/ta/id/51526-teritorijas-attistibasplanosanas-likums Accessed on 06/10/2020.

Teritorijas attīstìbas plānošanas likums / Law on Territorial Development Planning (13.10.2011). Law of the Republic of Latvia. Likumi.lv. Retrieved from: https://likumi.lv/ta/id/238807-teritorijasattistibasplanosanas-likums Accessed on 06/10/2020.

Teritorijas plānošanas likums / Spatial Planning Law (22.05.2002). Law of the Republic of Latvia. Likumi.lv. Retrieved from: https://likumi.lv/ta/id/63109-teritorijas-planosanas-likums Accessed on $06 / 10 / 2020$.

Thissen, M., Van Oort, F., Diodato, D., \& Ruijs, A. (2013). Regional Competitiveness and Smart Specialization in Europe. UK: Edward Elgar

Unterlass, F. et al. (2015). The relationship between export and technological specialisation profiles across EU Member States and regions and the identification of development potentials. WIFO Studies, WIFO, number 58911, December 2015. Austria: Österreichisches Institut für Wirtschaftsforschung.

Vesperis, V. (2012). Reǵionäläs attīstïbas novertê̌sana / Regional development assessment. Summary of the thesis for obtaining the doctoral degree. Latvia: Latvia University of Agriculture. Retrieved from: https://llufb.llu.lv/dissertation-summary/regionaldevelopment/V Vesperis promoc darba kopsavilkums 2012 LLU EF.pdf Accessed on $06 / 10 / 2020$.

Zeibote, Z. (2018). Klasteri kä reğgionälo politiku un konkurètspëju ietekmèjošs faktors / Clusters as a factor influencing regional policy and competitiveness. Summary of the thesis for obtaining the doctoral degree. Latvia: Baltic International Academy. Retrieved from: https://bsa.edu.lv/wp-content/docs/science/2020/zanezeibote.pdf Accessed on 06/10/2020.

Yfanti, S., Sakkas, N., \& Nistikaki, A. (2019). Environmental sustainability and regional competitiveness. Energy and Power Engineering, 13, 149-161. 